\title{
INVESTIGATIONS ON FARMERS' WILLINGNESS TO ASSOCIATE AND JOIN IN ENVIRONMENTAL RESPONSIBLE SHORT SUPPLY CHAIN IN ROMANIA
}

\author{
ANDREI, J. V. ${ }^{*}-$ ION, R. A. ${ }^{2}-$ CHIVU, L. $^{3}-$ POP, R. E. ${ }^{2}-$ MARIN, A. ${ }^{4}$ \\ ${ }^{I}$ Petroleum - Gas University of Ploiesti, Faculty of Economic Sciences \\ B-dul Bucuresti, No.39, 100680 Ploiesti, Prahova, Romania \\ ${ }^{2}$ Faculty of Agrifood and Environmental Economics, The Bucharest University of Economic \\ Studies, No.6, Piata Romana, 010374 Bucharest, Romania \\ ${ }^{3}$ National Institute for Economic Research - Romanian Academy \\ Calea 13 Septembrie 13, Casa Academiei Romane, 050711 Bucharest, Romania \\ ${ }^{4}$ The Research Institute for Agricultural Economics and Rural Development \\ Bulevardul Mărăști, No. 61, 011464 Bucharest, Romania \\ *Corresponding author \\ e-mail: andrei_jeanvasile@yahoo.com; phone: +40-72-761-5540 \\ (Received $4^{\text {th }}$ Oct 2018; accepted $2^{\text {nd }}$ Jan 2019)
}

\begin{abstract}
In contemporary agricultural based economies, smallholder farmers are encouraged to organize and reunite themselves into different forms of association, for overcoming major challenges and obstacles imposed by the market functionality and barriers, land grabbing and land fragmentations, ownership rights or reducing transaction costs. But farmers are often resistant to associate, due to the way in which cooperation was made in the previous regime in Romania. The objectives of this paper are to identify both the farmers' willingness to associate in any associative form, considering the current economic context in which cooperatives are established on voluntary bases, and also to highlight the determinants of their willingness to join an associative form from the broad perspective of a short supply chain. The research is specific targeted to for vegetables and fruits producers. The results provide an overview of the intensions of the farmers' willingness to associate and create better comprehension of this situation in the Romanian agriculture. Consequently, the paper points out, that the probability of farmers' willingness to adhere to a associative form or in a short supply chain environmental responsible is often hampering by factors as: age, education level, cultivated area, activity type, year of establishment, opportunities to access financial support which confirms the gap between economic necessity to associate and the traditional restrictions.
\end{abstract}

Keywords: supply chain, environmental farming, ecologic products, agricultural policy, holdings

\section{Introduction}

Emergent countries as Romania, with a significant share of the agricultural sector in the national economy provide a unique opportunity to study farmers' willingness to associate in any associative form and to adhere in environmental responsible short supply chain as land reforms have redistributed the land ownership rights and liberalized land exchange restrictions imposing the free market economy rules. While much studies has been written on land reforms (Cartwright, 2017), land ownership (Sabates-Wheeler, 2001; Vidican, 2009), land fragmentation (Thomas, 2006; Kuemmerle, 2009; Sikor, 2009) importance of agriculture in domestic economies (Aligica, 2003; Davidova et al., 2003; Mănescu et al., 2016; Aničić et al., 2018; Hu et al., 2018), farm restructuring and land grabbing (Van der Ploeg, 2015; Constantin, 
2017) in transition countries, still few researches have concentrated on providing formal conceptual and economic analysis of the farmers' willingness to associate and their determinants to form agricultural cooperatives and other forms of joint exploitation of agricultural potential.

The central goal of stimulating the process of associating agricultural producers in agricultural cooperatives or other forms of specific agricultural association is to establish viable agricultural production structures in private farming sector. However, in Romanian agricultural sector, land privatization and numerous land reforms has led to a more problematic economic and social situation by dividing large land properties, previously existing and economically efficient, into numerous small privately and less economic viability holdings. The excessive land ownership fragmentation has caused significant problems in valuing agricultural potential and in creating agriculture that fulfills the demands of the market economy by increasing competitiveness and living standards in rural areas.

The evolution of the farmers' willingness to associate in any associative form has a long history in Romanian agriculture. The Romanian agricultural sector has experienced numerous and often unfinished land reforms during the process of implementing and achieveing a well and functional market economy imperatives. As (Dale and Baldwin, 2000; Hartvigsen, 2014) argues in their studies, numerous farm structures and holdings have emerged during the reforms which are now, incompatible with modern agricultural practice and tendencies. The contradictory evolution of farmers' willingness to associate is often due to the historical background of land ownership situation triggered by collectivization process and sharing agricultural benefits among members. From this perspective, achieving a competitive and highly functional agricultural sector impose agricultural cooperation as a functional and potential instrument in stimulating the capitalization of the national agricultural potential and developing the short supply chains. Taking into account the evolution of national agricultural sector, the term "cooperation" raises many contradictions and emotional reactions to Romanian farmers, since it is linked to the forced cooperation during the communist period. At that time, the cooperatives were not established on the traditional cooperative principles and values: voluntary and open membership, democratic member control, autonomy and independence (ICA, 2018), and this is the reason why farmers are still resistant to cooperation. Despite the fact, that nowadays, cooperation is made on voluntary membership and farmers' willingness to associate and has a more comprehensive approach which is centered on the principles of efficiency and competitiveness and less on considerations of social nature, belonging to a social community or social group in rural area.

As in literature (Nosenzo and Tufano, 2017), voluntary participation has a strong, positive effect on cooperation, as reported by Nosenzo and Tufano (2017). Thereby, the main objectives of the research are to find whether the farmers want to join an associative form, in the current economic context in which cooperatives are established on voluntary bases, and to identify the determinants of farmers' willingness to join a short supply chain and an associative form. In this context, a need to explore the determinants and economic impacts of membership in farmer cooperatives and food supply chains in Romania is necessary in explaining the reasons of farmers' willingness or resistance to membership.

The relevance of the topic emerged from the low level of farm efficiency in Romania, attributed to the small size of farms. There are 3,342,185 holdings and 
12,502,535.5 ha of cultivated land, resulting an average farm size of 3.74 ha, as National Institute of Statistic of Romania reported for 2016 (NIS, 2018). Also, as it is reviled in some national studies (CRPE, 2016), in 2015, there were 743 agricultural cooperatives in Romania, most of them being found in the North-East region of the country, as reported by the National Trade Register Office. The Ministry of Agriculture and Rural Development presented that less than $1 \%$ of Romanian agricultural producers are part of associative structures, as compared to $34 \%$, the European Union average.

For overcoming this problem, some authors (Narrod et al., 2009, Bernard et al., 2010) consider that the solutions could be either farmers' association in different forms (marketing, selling or processing cooperatives, producers' organizations or agricultural associations), known in literature as horizontal integration (Malassis, 1992), or farmers' integration into a supply chain, known in literature as vertical integration. Both horizontal and vertical forms of integration lead to higher performance in carrying out the agricultural activities (Ion, 2005).

The term supply chain is defined by Malassis et al. (1992: p. 94) as the itinerary of a product or group of products within the agro-food system and comprising all agents and operations that contribute to the formation and transfer of products to the final stage of use. In some cases, the chains are long and complex, as reported by Manole et al. (2005), implying numerous agents and operations. Since every agent within the chain asks for a certain profit considering the activities performed, increasing, finally, the prices that the consumer pays for products, the need to shorten the chain has emerged.

The attempts to shorten the supply chains are encouraged and financed by the Ministry of Agriculture and Rural Development of Romania, through the National Program for Rural Development. Short supply chain is defined as the configuration of the food chain that does not involve more than one intermediary between producers and consumers (MARD, 2016: p. 43). A short supply chain implies fewer agents, but the same number of operations, meaning that the activities of the chain are performed by the remaining two agents - farmer and retailer (Marin et al., 2017).

Since the solution agreed to overcome the low level of farm's efficiency seems to be the producers' association, the public agricultural policy in Romania aims to encourage farmers to associate, using subsidies, financial support or preferential financial leverage for associative forms. If referring to fruits and vegetables branch, the public policy grants financial support to producers' organizations (Romanian Government Decision no.740/2017). Integration, including association, is also stimulated through the National Program for Rural Development in Romania, where one specific measure (16.4) refers to financial support for horizontal and vertical cooperation between the actors in the supply chain (MARD, 2017).

Understanding farmers' motivations for cooperation, and the tension associated, is important for the expectation management and funding efficiency (Wynne-Jones, 2017), at a time when great funding and support is being channelled through the European Union Common Agricultural Policy to encourage cooperative and collaborative practices (Prager, 2015).

In this context, the research of the farmers' willingness to join a short supply chain or an associative form environmental responsible is needed for justifying the state's financial efforts to fund the farmers' projects aiming to create short supply chains and to encourage the establishment of cooperatives. 
The questions arising are whether farmers want to join a supply chain or a cooperative or not, and what are the determinants of their membership. The answers to these issues are searched in this research.

Other additional objectives are considered within the study. Thus, research aims to find out the farmers' perceptions on different issues: the level of the state subsidies and other financial support, the public taxation in agriculture, the short supply chain functionality, and the association role within the short supply chain.

In achieving these issues, a survey of farmers across fifteen (15) counties in Romania has been conducted. The method used for data collection was the interview. The data were analyzed using SPSS. The hi2 test and coefficient of contingence were used to analyze the correlations between variables. The sample contains one hundred and forty (140) valid observations. Besides asking the farmers' willingness to join a short supply chain environmental responsible or a cooperative, the survey also asked the follow-up questions about the reasons why farmers do not want to join a short supply chain environmental responsible or an associative form of organization.

The relevance of the research lies in the economic, social and environmental benefits brought by collective actions in agro-food system. Short supply chains (vertical integration) and collective actions of farmers (horizontal integration) are studied in the light of multi-stakeholder cooperatives. When the two forms of integration are combined, they form multi-stakeholder cooperatives which bring together producers, processors and/or retailers, and consumers under one single enterprise. It has been demonstrated by Gonzales (2017) that multi-stakeholder cooperatives create more sustainable food flows between rural and urban areas and they overcome the limitations of conventional producers' cooperatives focused more on economic than social and environmental benefits.

The paper outcomes are expected to provide a specific framework for policy makers on economic, demographic and psychological factors that influence the farmers' willingness to join a short supply chain environmental responsible and an associative form of organization. Also, the main findings may contribute to develop policy initiatives to finance collective actions in food supply chains.

Following the introduction, the paper is structured into six parts, as follows. In Section 2, a holistic approach is taken to review the literature in the field of supply chains, integration and cooperation, with the final goal to establish the study hypotheses, in Section 3. The paper then proceeds to present the database and methodology, in Section 4, whereas, in Section 5, the main findings are discussed. Finally, the implications of the findings are considered and concluding remarks are drawn, in Section 6.

\section{Literature review}

There is abundant literature and numerous case studies and field research referring to agricultural integration, supply chains and farmers' associations. With respect to integration, Poole and Frece (2010: p. 7) recognized that it is a means of tackling poverty in rural areas, and that increasing vertically coordinated supply chains plays a significant role in linking smallholder farmers to more dynamic markets. Williamson (1985) showed that integration aim is to minimize transaction costs. Other authors (Neven and Reardon, 2004) argued that the supply chains need to be redesigned, advocating the development of new, smaller farmer markets closed to local residential 
areas that are able to facilitate an effective procurement system. This idea, linked to shortening the supply chain, meaning fewer agents, is sustained by Poole and Frece (2010: p. 100), as well. They found that one approach to the fair-trade sector consists on creating links between farmers and traders, importers or even retailers, thereby cutting out middlemen and maximizing profit margins for farmers.

Supply chains, described as all steps involved in production, manufacturing and distribution of food until its final consumption (Stone and Rahimifard, 2018), face vulnerabilities due to the limited shelf life of food, and variability in quality and availability of raw materials as organic products (Dani and Deep, 2010).

In respect to the process of collective collaboration in agriculture, many papers studied both its benefits and failure. The term "smallholder farmers" association" is referring to diverse types of groups who act collectively in order to benefit either as individuals or as a group (Poole and Frece, 2010: p. 17). The terminology used in the literature varies from terms such as cooperatives, farmer collectives, farmer associations, rural community enterprises, rural producer associations, community enterprises, and farmer organizations (Donovan et al., 2008). A cooperative is defined as "an autonomous association of persons united voluntarily to meet their common economic, social, and cultural needs and aspirations through a jointly owned and democratically-controlled enterprise" (ICA, 2018). Cooperatives are considered to play significant economic roles by reducing transaction costs and improving the bargaining power of individuals (Bonin et al., 1993), as a consequence, they are recognized to fight poverty in rural areas (FAO, 2005).

Some studies highlighted the socio-economic benefits of cooperatives. Fischer and Qaim (2012) reported the positive impact of cooperative membership on production and productivity in Ethiopia. Abate et al. (2014) claimed that improved technical efficiency of member of agricultural cooperatives is obtained due to better access to productive inputs and services, as compared to non-members. Marketing cooperatives allow small farmers to get better price by overcoming the powerful oligopolistic firms (Bontems and Fulton, 2009). Moreover, grace to marketing cooperatives, farmers have a better position for price negotiation and gain access to markets that they cannot access individually (Camanzi et al., 2011).

But cooperatives cannot be simply generalized as benefiting all their members and all locations (Mojo et al., 2017). Studies show that their performance varies across countries, regions and even sector (Bernard et al., 2010), and the skills of the managers and the administrative organization determine their success. Cooperative management seems to be the weak point of associative forms in Romania. Also, farmers' resistance to association is a characteristic of the Romanian agricultural system, as many authors observed in their works (Marin et al., 2016).

There are both practical and theoretical explanations of the failures of collective organization. Sound financial management, good organizational governance and the potential for free riding, remain problems for the more complex cooperatives (Poole and Frece, 2010: p. 46). But at the same time, there are fundamental reasons for collaborating: the potential for exploiting production and managerial economies of scale, overcoming market entry barriers, reducing transaction costs and cultivating supply chain relationships.

The term "new cooperative" has emerged (Cook and Chaddad, 2004) referring to the market-oriented producer organizations, and extending this commercial orientation further by linking ownership rights, investment and governance. Whereas traditional 
cooperative forms are described as being defensive, aiming to protect farmers and minimize risk, new generation cooperatives can be seen as 'offensive', able to cope with falling profit and income risks.

Not only horizontal integration creates new cooperatives, but also vertical integration advocates fundamental changes in supply chains in the advanced economies. A shift from competitive vertical relations towards the cooperative organization of the supply chain, or supply chain management has been identified by Poole and Frece (2010: p. 21).

Table 1 summarizes the main findings in the field of farmers' cooperation, supply chains and their economic implications, relevant for our research.

The links between supply chains and collective actions are also discussed in many papers. Lund (2012) studied the place of the modern multi-stakeholders' cooperatives in food and farming in the context of the emerging concept of value chains, which implies approaches beyond economics. The activities along value chains involve many cultural and social aspects such as taste, identity, connection with nature and community (Baggini, 2014). Bauwens and Kostakis (2014) go beyond multi-stakeholder cooperatives and value chains and call for "open coops", which combines multistakeholder ship and the co-production of the value chain by everyone affected by a provisioning service. The cooperatives are described as potential leading actors in shortened food chains, since they make possible economies of scope or synergy, versus simplistic economies of scale (Marsden et al., 2002).

Table 1. Main findings in the field of farmers' cooperation, supply chains and their economic implications

\begin{tabular}{|c|c|c|}
\hline Issue & Explanation & Relevant studies \\
\hline $\begin{array}{l}\text { Vertical integration of } \\
\text { activities within supply } \\
\text { chains increases } \\
\text { performance }\end{array}$ & $\begin{array}{c}\text { Reduced transactions costs, smallholder } \\
\text { farmers are closer to more dynamic markets, } \\
\text { overcoming market entry barriers, increasing } \\
\text { equity }\end{array}$ & $\begin{array}{l}\text { Ion (2005), Lund (2012), } \\
\text { Marin et al. (2016), Marin et } \\
\text { al. (2017), New (1997: p. } \\
\text { 19), Poole and Frece (2010), } \\
\text { Williamson (1985) }\end{array}$ \\
\hline $\begin{array}{l}\text { Horizontal integration of } \\
\text { activities within supply } \\
\text { chains increases } \\
\text { performance }\end{array}$ & $\begin{array}{c}\text { Collective actions include greater } \\
\text { accessibility of finance, technology and } \\
\text { market information; improve farmer returns } \\
\text { by lowering production costs, } \\
\text { counterbalancing the negative economic } \\
\text { impacts of market power and reducing } \\
\text { producer income risks }\end{array}$ & $\begin{array}{c}\text { Abate et al. (2014), Bonin et } \\
\text { al. (1993), Bontems and } \\
\text { Fulton (2009), Camanzi } \\
\text { et al. (2011), Cook and } \\
\text { Chaddad (2004), Markelova } \\
\text { et al. (2009), Wynne-Jones } \\
\text { (2017) }\end{array}$ \\
\hline $\begin{array}{l}\text { The length of the supply } \\
\text { chain must be reduced }\end{array}$ & $\begin{array}{l}\text { In longer chains, too many agents ask for } \\
\text { profit, increasing, as such, the prices that the } \\
\text { final consumer pays for food. } \\
\text { In shorter chains, there are direct links, } \\
\text { cutting out middlemen and maximizing profit } \\
\text { margins for farmers }\end{array}$ & $\begin{array}{l}\text { Chirwa et al. (2005), } \\
\text { Manole et al. (2005), Marin } \\
\text { et al. (2016), Poole and } \\
\text { Frece (2010) }\end{array}$ \\
\hline $\begin{array}{c}\text { Multi-stakeholder } \\
\text { cooperatives combine } \\
\text { supply chains and collective } \\
\text { actions (they bring together } \\
\text { producers, processors and/or } \\
\text { retailers, and consumers } \\
\text { under one single enterprise) }\end{array}$ & $\begin{array}{l}\text { Multi-stakeholder cooperatives create more } \\
\text { sustainable food flows between rural and } \\
\text { urban areas. } \\
\text { Multi-stakeholder cooperatives have the } \\
\text { potential to generate a diverse range of more- } \\
\text { than-economic benefits: sectorial, legal, } \\
\text { cultural, policy and public procurement, } \\
\text { academic }\end{array}$ & $\begin{array}{l}\text { Baggini (2014), Bauwens } \\
\text { and Kostakis (2014), Gray } \\
\text { and Stevenson (2008), } \\
\text { Gonzales (2017), Lang et al. } \\
\text { (2009), Lund (2012), } \\
\text { Mooney (2004) }\end{array}$ \\
\hline
\end{tabular}

Edited by the authors 
Although there is abundant literature in the field of farmers' cooperation, supply chains environmental responsible and their economic implications, the need of analysing these phenomena in Romania arises from the agriculture's particularities in this country, especially by the existence of numerous and small agricultural holdings. The land reforms have determined extreme forms of land use fragmentation which has generated and maintained for a long time a small peasant property with a low degree of efficiency and poorly technically endowed. An opposite situation is drafted in Bulgaria, where according to (Lerman et al., 2004) more than $40 \%$ of land is being farmed in associations. Still, for Romania, the high fragmentation of agriculture structures creates premises for farmers' association as viable solution for overcoming market entry barriers, and increasing equity along the chain.

Romanian agriculture is facing a long and difficult process of land aggregation, marked often by the resistance of farmers to reunite in holdings. Despite the fact that, domestic agriculture is trying to diminish the contradictory effects of the dominance of the subsistence farming imposed by the peasant property, there are successful attempts in determining the farmers' association and achieving a comparative convergence level with the European agricultural model. The need for farmers' association and cooperation emerge as a stringent necessity imposed by real and determinant factors as, low productivity in agriculture, poor access to markets, low investment capacity, technical and technological capital shortage, and low levels of competitiveness.

This study conducted a survey to investigate the factors influencing the Romanian farmers' willingness to join a short supply chain environmental responsible and an associative form of organization. Surveys and behavioural approaches in agricultural studies are not new. They cover a broad range of studies that employ quantitative methodologies to the investigation of decision-making and farmers' willingness to adopt new technologies, instruments, services etc. Folorunso and Ogunseye (2008) explored the farmers' acceptance of a knowledge management system in agricultural extension services. Heyder et al. (2010) examined the major factors influencing the investment behaviour of agribusiness firms. Pappa et al. (2018) identified the drivers that determine the acceptance and use of electronic traceability systems in agro-food supply chains. Survey has been used before to understand consumers' preferences for vegetables and fruits (Ion, 2015), using as dependent variables consumer preferences for preserved vegetables and fruits and as independent variables gender, age, income. Adrian et al. (2005) investigated the perception and attitudinal characteristics of farmers who plan to adopt precision agriculture, using a survey to measure constructs of perception and attitudes. As such, our intention in this paper is to explore the changes in food chains and cooperation phenomenon in Romania, considering the financial efforts of the public agricultural policy to fund the creation of short supply chains environmental responsible and the establishment of associative forms of organization. Our main contribution is to add to the discussions and enrich the evidence supporting different factors which determine farmers' willingness to join short supply chains environmental responsible and cooperatives, including demographic and economic variables, economic impacts of membership, and farmers' perceptions on financial and fiscal issues in agriculture.

\section{Research hypotheses}

Considering the results of the previous studies described in Section 2, four hypotheses (H1 to H4) emerged and need to be studied subsequently, as: 
H1: Socioeconomic and demographic factors influence the farmers' willingness to join a short supply chain or an associative form of organization.

This hypothesis is based on the results of other studies (Marin et al., 2016; Marin et al., 2017), showing that membership in an associative form varies with the farmer's age and the date of establishment of the holding. Mojo et al. (2017) found that the probability of farmers' membership decision increases with age, education level, family size, social networks, land property and accessibility to cooperatives. Adrian et al. (2005) argued that perceptions of net benefit, farm size and farmer educational levels positively influenced the intention to adopt precision agriculture technologies.

$\mathrm{H} 2$ : Membership in a collective form of organization and a short supply chain has a positive impact on farm income and assets.

This hypothesis is based on the assumptions mentioned in Table 1 and it is sustained by many other studies (Abate et al., 2014, Bonin et al., 1993, Chirwa et al., 2005, Cook and Chaddad, 2004, Manole et al., 2005, Markelova et al., 2009, Marin et al., 2016). They show that both vertical and horizontal integration of chain activities increases performance.

H3: Farmers are resistant to join a short supply chain or an associative form.

This presumption is based on emotional connotations related to the communist period when association was not established on voluntary bases. One study regarding the problems encountered by the Romanian farmers reported that $62 \%$ of subjects do not intent to associate in the future (Marin et al., 2016: p. 19). The longstanding question raised in the literature - whether farmers are inherently disposed towards selfreliance and independent actions rather than collective and collaborative working (Wynne-Jones, 2017).

H4: Farmers' reasons for not joining short supply chains and associative forms of organizations are linked to the lack of trust in other members, the lack of legislation and to bureaucracy.

The assumption is made on people resistance to cooperation as experienced in the previous period and on the results of other research (Marin, 2017) showing that farmers do not want to associate because they do not trust other people, and that there are no legal support and preferences or incentives for cooperatives.

Poole and Frece (2010), Turek et al. (2007), Ion (2005) found that farmers act collectively to get accessibility of finance, technology and market information and to enter the final consumer market. By fostering long-term relationships rather than punctual commercial transactions, Lund (2012) argued that membership in a collective form can overcome the higher transactional costs that traditional economic theory would expect from the involvement of separate parts. Economic motivation is a determinant of the choice to become a cooperative member, as Wynne-Jones (2017) found in the research studying farmer cooperation drivers and effects.

\section{Experimental section}

The survey data were collected from randomly chosen farmers across 15 counties in Romania, from January to April 2018. The response rate is $92 \%$ and there are 140 valid observations out of 152 responses. The sampling method is based on voluntary selection of units, which is a non-probabilistic method, considering rational choices (Porojan, 1993: p. 205). Sample inclusion is based on the voluntary option of individuals to participate in the sample. The survey questions include farmers' willingness to 
participate in short supply chains and cooperatives, farms' characteristics, and farmers' socio-demographic characteristics.

In the questionnaire, the key questions involve two parts. The first question is phrased "If you are not part of an associative form, do you consider to associate in the near future?" (Q5). The respondents could answer yes, showing their willingness to associate, or no, showing their resistance to association. If no, the respondent is asked to provide reasons (Q6: What are the reasons why you did not associate?).

The second key question is phrased "Do you intend to integrate your exploitation into a short supply chain of vegetables/fruits?" (Q14). The respondents could answer yes, showing their willingness to join a short value chain, or no, showing their resistance to join a short value chain. Explanatory factors considered in this piece of research are: the year of farmer's establishment, the form of farmer's organization, holding surface, crops' structure, farm's revenues, the type and level of farmer's financial resources, occupation, education, studies in agriculture/horticulture, age, gender and nationality (Table 2).

Table 2. Dependent variables used in the model and other studies which considered them relevant

\begin{tabular}{|c|c|c|}
\hline Variable & Explanation & Relevant studies \\
\hline $\begin{array}{l}\text { Farmer's characteristics: } \\
\text { age, gender, nationality, } \\
\text { residence, civil status, } \\
\text { education, studies in } \\
\text { agriculture/horticulture } \\
\text { occupation }\end{array}$ & $\begin{array}{l}\text { Demographic characteristic of the subjects may } \\
\text { influence their decision to join a short supply chain } \\
\text { or an associative form of organization. } \\
\text { The age of the household head is positively } \\
\text { correlated with participation in cooperatives. } \\
\text { It is assumed that the farmers who have studies in } \\
\text { the field of agriculture or horticulture make } \\
\text { informed choices and decisions }\end{array}$ & $\begin{array}{l}\text { Bernard (et al., 2013), } \\
\text { Burton (2004), } \\
\text { Hansson et al. (2012), } \\
\text { Knowler and Bradshaw } \\
\text { (2007), Marin et al. } \\
\text { (2016), Montefrio } \\
\text { (2016), Nosenzo and } \\
\text { Tufano (2017), } \\
\text { Prokopy et al. (2008), } \\
\text { Zhong (2016) }\end{array}$ \\
\hline $\begin{array}{c}\text { Farm's characteristics: } \\
\text { year of establishment } \\
\text { (farming experience), type } \\
\text { of activity, farm size, } \\
\text { structure of crops, financial } \\
\text { resources }\end{array}$ & $\begin{array}{l}\text { It is assumed that farmer's experience influences its } \\
\text { process of decision making, including the decision } \\
\text { of joining a short supply chain or a cooperative. } \\
\text { The level of financial resources influence the } \\
\text { farmers' decisional autonomy and, as such, their } \\
\text { willingness to make the decisions on joining short } \\
\text { supply chains and collective forms of organization }\end{array}$ & $\begin{array}{l}\text { Bernard (et al., 2013), } \\
\text { Gonzales (2017), } \\
\text { Knowler and Bradshaw } \\
\text { (2007), Marin et al. } \\
\text { (2016), Pappa et al. } \\
\text { (2018), Prokopy et al. } \\
\text { (2008), Zhong (2016) }\end{array}$ \\
\hline
\end{tabular}

Edited by the authors

\section{Findings}

The key questions of the research are: Are you part of an associative form in agriculture? (Q3), Are you part of a short value chain for vegetables and fruits? (Q4), If you are not part of an associative form, do you consider association in the near future? (Q5), What are the reasons why you did not associate? (Q6) and Do you intend to integrate your exploitation into a short supply chain of vegetables/fruits? (Q14). The answers to these questions show that $81.4 \%$ of the respondents are not part of an associative form and $78.6 \%$ are not part of a short value chain for vegetables and fruits. $82.1 \%$ of the respondents want to join an associative form and $67.1 \%$ of the respondents want to integrate their business into a short supply chain, in the near 
future. The main reason why farmers do not cooperate is the lack of legislation to support small and medium-sized producers, since $34.3 \%$ of the farmers have chosen this answer. Another significant reason is the high level of taxation $(29 \%)$.

To achieve the research goals, the determinants of association are analysed, based on the correlations between variables. The results of the survey have been analysed using the values of the $\mathrm{hi}^{2}$ test and the values of the contingency coefficient calculated with SPSS (Analyse-Descriptive Statistics-Crosstabs-Statistics-Chisquare/Contingency coefficient). Correlations between variables exist when the value of the $\mathrm{hi}^{2}$ test do not exceed .05. Depending on the value of the contingency coefficient, this link may be of weak, medium or strong intensity.

The first assumption is that the socioeconomic and demographic factors influence the farmers' willingness to join a short supply chain or an associative form of organization (H1). To test this hypothesis, the correlations between variables are analysed. The dependent variable is the farmers' affiliation to an associative form of organization $(\mathrm{Q} 3)$, and the independent variables are the farm's characteristics: the year of starting the activity (Q1), the activity type $(\mathrm{Q} 2)$, the holding surface $(\mathrm{Q} 7)$, the structure of crops (Q8.1), the exploitation's dimension (Q8.2), the estimated revenues (Q11), the subsidies (Q22), the accessing of European funds (Q25), and the farmer's characteristics: occupation $(\mathrm{Q} a)$, education $(\mathrm{Qb})$, studies in the field of agriculture $(\mathrm{Qc})$, age $(\mathrm{Qd})$, gender $(\mathrm{Qe})$, nationality $(\mathrm{Qf})$, marital status $(\mathrm{Qg})$.

Table 3 and Figures 1,2 and 3 illustrate the results of the analysis. Medium correlations have been found between the farmers' affiliation to an associative form of organization and the holding surface, because the value of hi $^{2}$ test is .005 , lower than .05 , and the value of the contingent coefficient is .308 , over .300 . It was noticed that farmers holding agricultural areas ranging from 1 to 5 ha are not part of an associative form.

Weak correlations were found between the farmers' affiliation to an associative form of organization and the activity type, the estimated revenues, the subsidies, the farmer's occupation and education level, where the values of $\mathrm{hi}^{2}$ test are lower than .05 , and the value of the contingent coefficient are below .300. Most of the farmers who act as physical persons do not belong to an associative form of organization, but some of the farmers who act as legal persons do belong to associative forms. Farmers with high income are part of associative forms, compared to farmers with lower income. Persons who graduated higher education are likely to associate, as compared to people who graduated only secondary schools.

There are no significant correlations between farmers' affiliation to an associative form of organization and the year of starting the activity, the structure of crops, the exploitation's dimension, the accessing of European funds, studies in the field of agriculture, age, gender, nationality, marital status.

Linear and positive relationships have been found between associative membership and holding surface (Fig. 1), supply chain membership and activity type (Fig. 2) and supply chain membership and holding surface (Fig. 3).

Medium correlations were found between the farmers' affiliation to a short supply chain environmental responsible and the activity type and the size of the farm, because the values of the $\mathrm{hi}^{2}$ test are lower than .05 , and the values of the contingent coefficients are .319, respectively .308 (Table 3). Farmers who act as physical persons and who hold small agricultural areas belong to a short supply chain environmental responsible. 
Table 3. The model estimated results for the hypothesis "Socioeconomic and demographic factors influence the farmers' willingness to join a short supply chain or an associative form of organization" (HI)

\begin{tabular}{c|c|c}
\hline \multirow{2}{*}{ Independent variable } & \multicolumn{2}{|c}{ Dependent variable } \\
\cline { 2 - 3 } & $\begin{array}{c}\text { Q3: Affiliation to an associative } \\
\text { form of organization }\end{array}$ & $\begin{array}{c}\text { Q4: Affiliation to a short value } \\
\text { chain }\end{array}$ \\
\hline Q1: year of starting the activity & .0369 & .777 \\
\hline Q2: activity type & .040 & .007 \\
\hline Q7: holding surface & $.277^{*}$ & $.319^{*}$ \\
\hline Q8.1: structure of crops & .005 & .007 \\
\hline Q8.2: exploitation dimension & $.168^{*}$ & $.308^{*}$ \\
\hline Q11: estimated revenues & .162 & .965 \\
\hline Q22: subsidies & .009 & .131 \\
\hline Q 25: the accessing of European & $.252^{*}$ & .594 \\
\hline funds & .049 & .504 \\
\hline Qa: occupation & $.167^{*}$ & .715 \\
\hline Qb: education level & .167 & .002 \\
\hline Qc: specialized studies in & .009 & $.285^{*}$ \\
\hline agriculture & $.251^{*}$ & .616 \\
\hline Qd: age & .002 & .683 \\
\hline Qe: gender & $.281^{*}$ & .691 \\
\hline Qf: nationality & .117 & .287 \\
\hline Qg: marital status & .968 & .610 \\
\hline So & .315 & 54
\end{tabular}

Source: results of the model. The results show the values of $\mathrm{hi}^{2}$ test. The values symbolized with $*$ represent the values of the contingent coefficients, calculated only for those variables for which the values of $\mathrm{hi}^{2}$ test are lower than .05

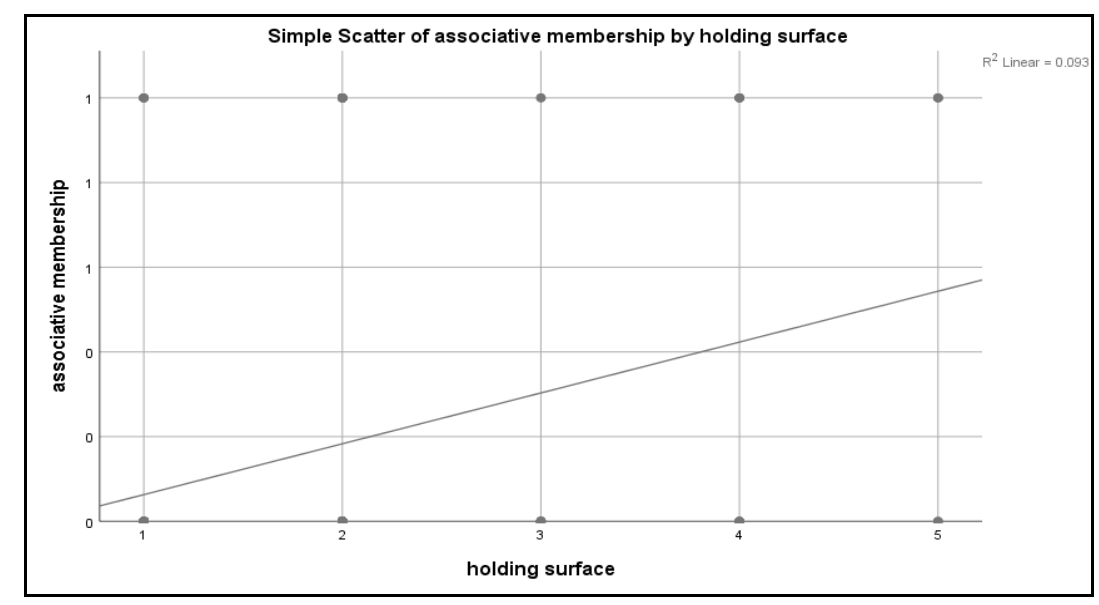

Figure 1. Correlations between the variables associative membership and holding surface. (Source: results of the model. The charts are built only for those variables in Table 3 for which the values of the $\mathrm{hi}^{2}$ test are lower than .05 and the values of the contingent coefficients are higher than .300) 


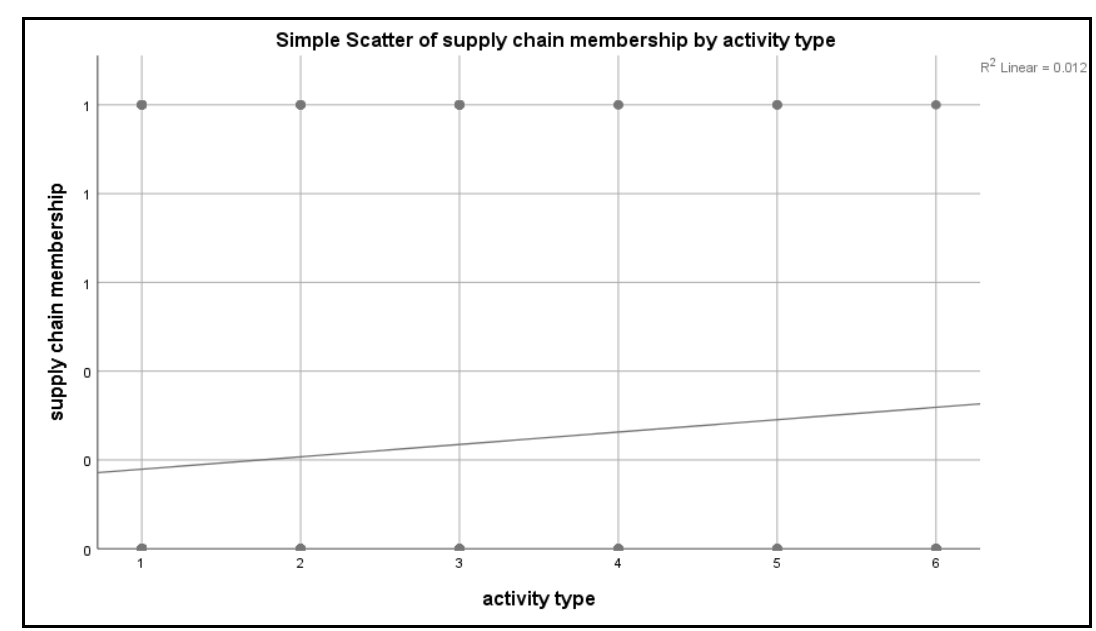

Figure 2. Correlations between the variables supply chain membership and activity type. (Source: results of the model. The charts are built only for those variables in Table 3 for which the values of the $\mathrm{hi}^{2}$ test are lower than .05 and the values of the contingent coefficients are higher than .300)

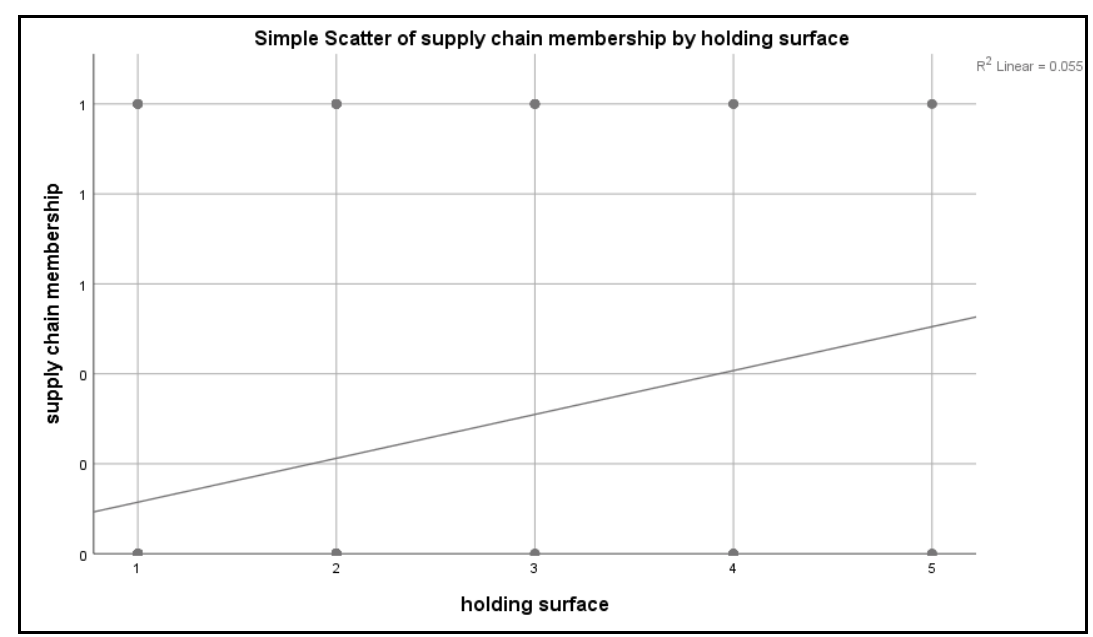

Figure 3. Correlations between the variables supply chain membership and holding surface. (Source: results of the model. The charts are built only for those variables in Table 3 for which the values of the $\mathrm{hi}^{2}$ test are lower than .05 and the values of the contingent coefficients are higher than .300)

Weak correlation is found between the farmers' affiliation to a short supply chain and the farmer's education level, because the value of the contingent coefficient is 285 . Persons who graduated higher education are likely to belong to a short supply chain environmental responsible, as compared to people who graduated only secondary schools. There are no significant correlations between farmers' affiliation to a short supply chain environmental responsible and the year of starting the activity, the structure of crops, the exploitation's dimension, estimated revenues, subsidies, the accessing of European funds, occupation, studies in the field of agriculture, age, gender, nationality, marital status. The second assumption is that "Membership in a collective form of organization and a short supply chain has a positive impact on farm income and assets" (H2). The dependent variable is farm's income and assets (Q11) and the 
independent ones are the affiliation to an associative form of organization (Q3) and the affiliation to a short supply chain (Q4). The results are presented in Table 4.

Table 4. The model estimated results for the hypothesis "Membership in a collective form of organization and a short supply chain has a positive impact on farm income and assets" (H2)

\begin{tabular}{c|c}
\hline Independent variable & $\begin{array}{c}\text { Dependent variable } \\
\text { Q11: Farm's income and assets }\end{array}$ \\
\hline Q3: Affiliation to an associative form of \\
organization & .009 \\
\hline Q4: Affiliation to a short value chain & $.252^{*}$ \\
\hline
\end{tabular}

Source: results of the model. The results show the values of $\mathrm{hi}^{2}$ test. The value symbolized with * represents the value of the contingent coefficient, calculated only for those variables for which the values of hi $^{2}$ test are lower than .05

Weak correlation has been found between farm's income and assets and farmers' affiliation to an associative form of organization, because the value of the $\mathrm{hi}^{2}$ test is below .05 and the contingent coefficient is .252 , lower than .300. Farmers with higher levels of income are likely to belong to an associative form of organization. There are no significant correlations between the farm's income and assets and the farmers' affiliation to a short supply chain environmental responsible, because the value of the $\mathrm{hi}^{2}$ test is over 05 .

The third assumption is that "Farmers are resistant to join a short supply chain or an associative form" (H3). The answers to the questions: If you are not part of an associative form, do you consider association in the near future? (Q5) and Do you intend to integrate your exploitation into a short supply chain of vegetables/fruits? (Q14) show that most of the farmers $(82.1 \%)$ want to join an associative form of organization and $67.1 \%$ of the respondents want to integrate their business into a short supply chain environmental responsible. The hypothesis is not validated.

For analysing the reasons why some farmers are resistant to association and integration, the determinants of this resistant are studied. The dependent variables are the farmers' willingness to associate (Q5) and their willingness to join a short supply chain (Q14). The independent variables are the farm's characteristics: the year of starting the activity (Q1), the activity type (Q2), holding surface (Q7), the structure of crops (Q8.1), the exploitation's dimension (Q8.2), the estimated revenues (Q11), the subsidies (Q22), the accessing of European funds (Q25), and the farmer's characteristics: occupation $(\mathrm{Qa})$, education $(\mathrm{Qb})$, studies in the field of agriculture $(\mathrm{Qc})$, age (Qd), gender (Qe), nationality (Qf), marital status (Qg) (Table 5).

Linear and positive relationships have been found between the variables willingness to associate and year of starting the activity (Fig. 4), willingness to associate and holding surface (Fig. 5), willingness to join a short supply chain and year of starting the activity (Fig. 6).

Medium correlations have been found between the farmers' willingness to associate and the year of starting the activity and the surface of the farm, because the values of the $\mathrm{hi}^{2}$ test are below .05 and the values of the contingent coefficients are over .300 . Respondents who recently started the activity and who exploit smaller areas of land are willing to join an associative form of organization, as compared to others. 
Table 5. The model estimated results for the hypothesis "Farmers are resistant to join a short supply chain or an associative form" (H3)

\begin{tabular}{|c|c|c|}
\hline \multirow[b]{2}{*}{ Independent variable } & \multicolumn{2}{|c|}{ Dependent variable } \\
\hline & $\begin{array}{l}\text { Q5: Willingness to } \\
\text { associate }\end{array}$ & $\begin{array}{l}\text { Q14: Willingness to join a short } \\
\text { supply chain }\end{array}$ \\
\hline Q1: year of starting the activity & $\begin{array}{l}.006 \\
.321 * \\
\end{array}$ & $\begin{array}{l}.001 \\
.313^{*} \\
\end{array}$ \\
\hline Q2: activity type & $\begin{array}{l}.009 \\
.252 *\end{array}$ & .080 \\
\hline Q7: holding surface & $\begin{array}{l}.002 \\
.308^{*}\end{array}$ & .362 \\
\hline Q8.1: structure of crops & .530 & .473 \\
\hline Q8.2: exploitation dimension & .507 & .129 \\
\hline Q11: estimated revenues & .878 & .375 \\
\hline Q22: subsidies & $\begin{array}{l}.020 \\
.198 *\end{array}$ & .251 \\
\hline Q 25: the accessing of European funds & .480 & $\begin{array}{l}.045 \\
.203 *\end{array}$ \\
\hline Qa: occupation & .809 & .941 \\
\hline Qb: education level & $\begin{array}{l}.021 \\
.229 * \\
\end{array}$ & .761 \\
\hline Qc: specialized studies in agriculture & .861 & .092 \\
\hline Qd: age & .124 & .088 \\
\hline Qe: gender & .697 & .540 \\
\hline Qf: nationality & .091 & .071 \\
\hline Qg: marital status & .143 & .537 \\
\hline
\end{tabular}

Source: results of the model. The results show the values of $\mathrm{hi}^{2}$ test. The values symbolized with $*$ represent the values of the contingent coefficients, calculated only for those variables for which the values of $\mathrm{hi}^{2}$ test are lower than .05

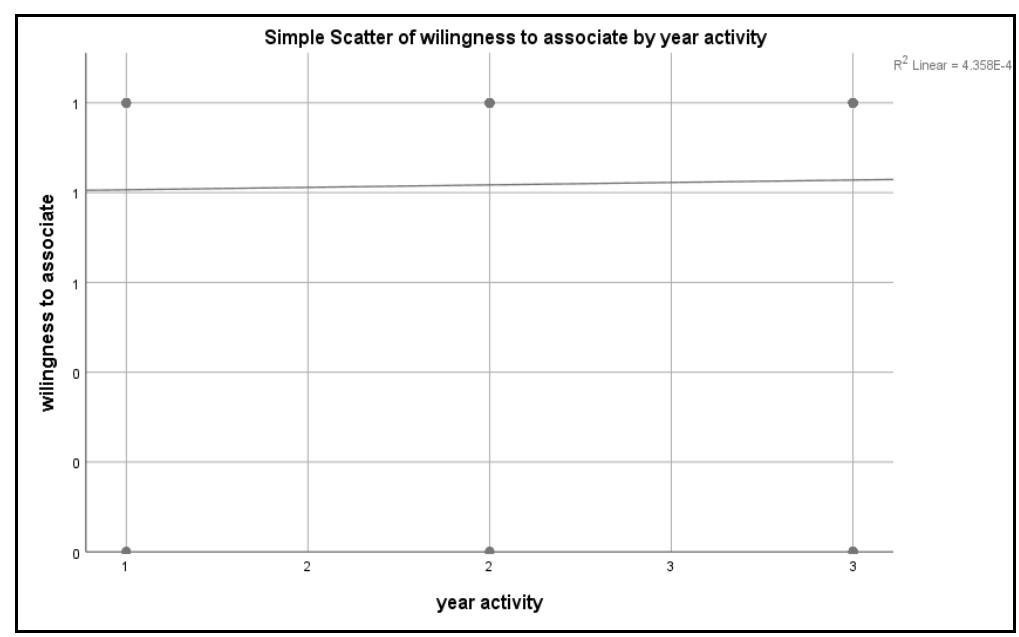

Figure 4. Correlations between the variables willingness to associate and year of starting the activity. (Source: results of the model. The charts are built only for those variables in Table 5 for which the values of the $\mathrm{hi}^{2}$ test are lower than .05 and the values of the contingent coefficients are higher than .300) 


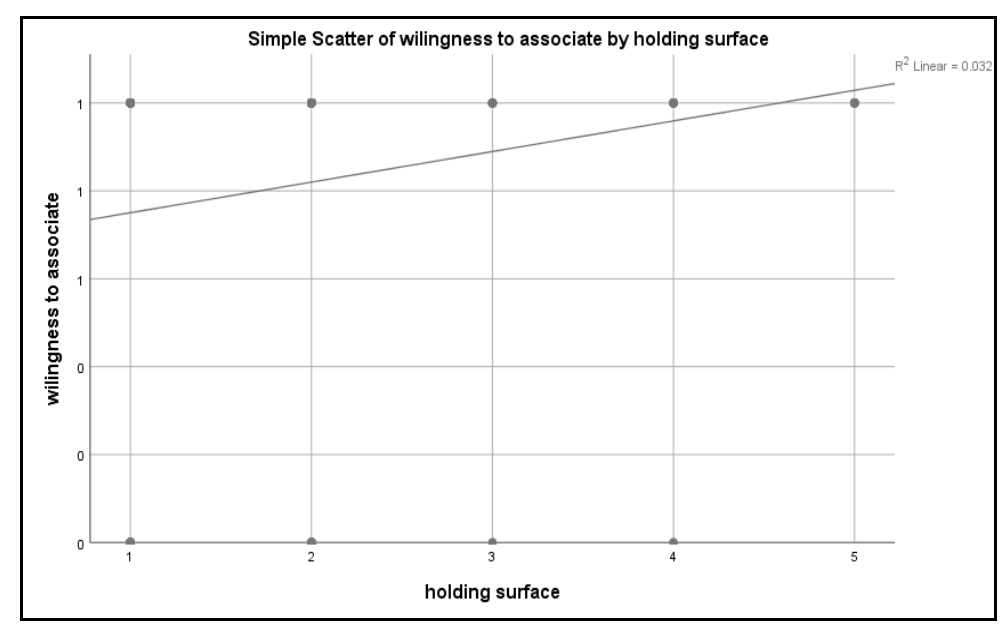

Figure 5. Correlations between the variables willingness to associate and holding surface. (Source: results of the model. The charts are built only for those variables in Table 5 for which the values of the $\mathrm{hi}^{2}$ test are lower than .05 and the values of the contingent coefficients are higher than .300)

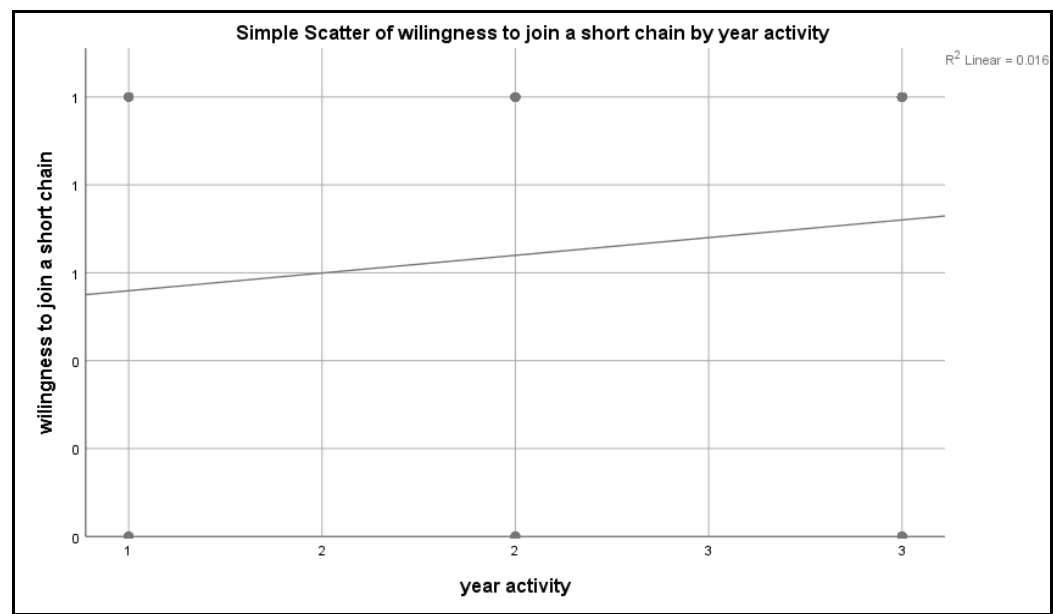

Figure 6. Correlations between the variables willingness to join a short supply chain and year of starting the activity. (Source: results of the model. The charts are built only for those variables in Table 5 for which the values of the hi ${ }^{2}$ test are lower than .05 and the values of the contingent coefficients are higher than .300)

Weak correlations have been found between farmers' willingness to associate and the activity type, the access to subsidies and the farmer's education, because the values of the $\mathrm{hi}^{2}$ test are below .05 , but the values of the contingent coefficients are lower than .300. Physical persons who never accessed subsidies before and who have graduated higher education are more likely to associate, as compared to others.

No significant correlations have been found between the farmers' willingness to associate and the crops' structure, the farm's size, the estimated revenues, the access to European funds, occupation, specialized studies in agriculture, age, gender, nationality, and marital status.

Medium correlations are found between farmers' willingness to join a short supply chain and the year of starting the activity, because the value of the hi ${ }^{2}$ test is below .05 
and the value of the contingent coefficient is .313, higher than .300 . People who started an agricultural business after 2017 want to be part of a short chain more than others.

Weak correlations have been found between farmers' willingness to join a short supply chain and the possibility to access European funds, because the value of the $\mathrm{hi}^{2}$ test is below .05, but the values of the contingent coefficient is .203, lower than .300 . People wishing to access European funds want more than others to integrate into a short supply chain.

No significant correlations have been found between the farmers' willingness to join a short supply chain and the activity type, the holding surface, the structure of crops, the exploitation's dimension, the estimated revenues, the subsidies, and the farmer's characteristics: occupation, education, studies in the field of agriculture, age, gender, and nationality.

The fourth assumption is that "Farmers' reasons for not joining short supply chains environmental responsible and associative forms of organizations are linked to the lack of trust in other members, the lack of legislation and to bureaucracy" (H4). To test this hypothesis, the answers to the question "What are the reasons why you did not associate?" are presented in Figure 7.

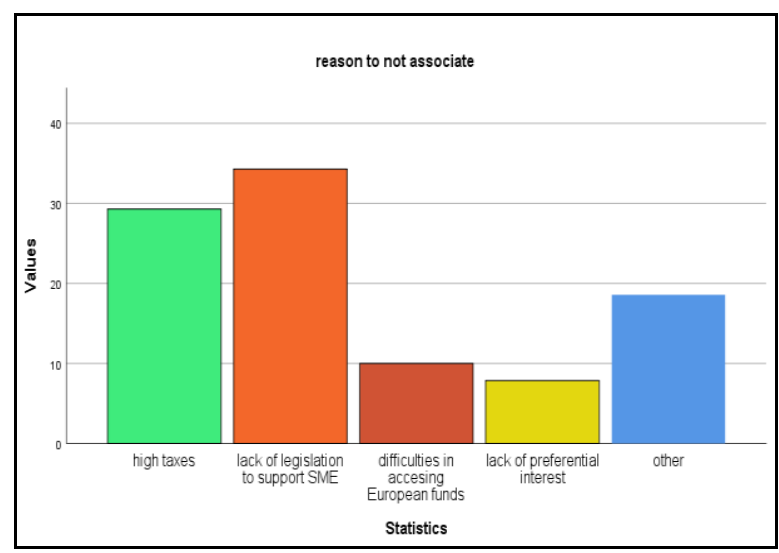

Figure 7. Reasons why farmer do not want to associate. (Source: authors' own computations)

Thus, the main reasons why the respondents did not associate are related to the legislation in force which is not supporting enough the associative forms, and the high level of taxes. For other reasons, the respondents mentioned the complex bureaucracy and the fact that they had no one to associate with, as well as the lack of trust. Hypothesis 4 is confirmed. Other objectives of the paper are to identify farmers' perceptions on the benefits of the short supply chain, and on the level of the state subsidies and taxes. The farmers' perceptions on the benefits of the short supply chain environmental responsible and association are presented in Figures 8 and 9.

Most people considered the short supply chain functional, since the average score is 3.08 , on a scale from 1 to 5. Farmers consider that the association has a beneficial role in shortening the chain, since the most of the respondents (42.1) answered that farmers benefit from the association and 31.4 of them answered that the role of the association is very beneficial (Fig. 9). Moreover, high correlation has been found between the farmers' age and their perceptions on the role of the association in shortening the supply chain. People aged at first intervals (18-25 years old and 26-40 years old) consider that this role is beneficial to very beneficial. 


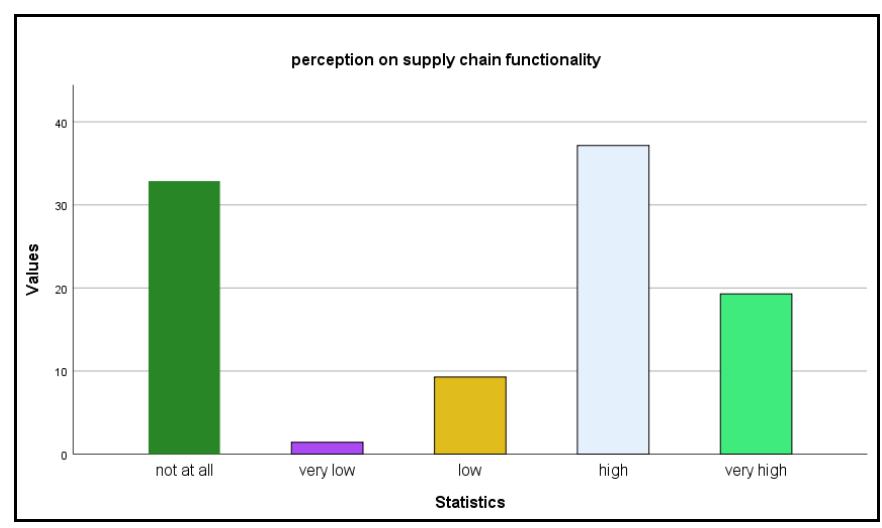

Figure 8. Farmers' perceptions on supply chain functionality. (Source: authors' own computations)

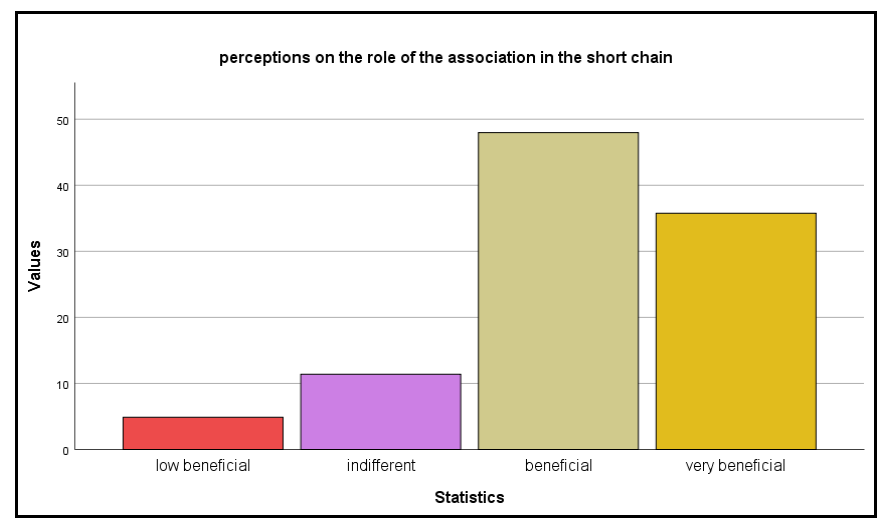

Figure 9. Farmers' perceptions on the role of the association in the supply chain shortening. (Source: authors' own computations)

The farmers' perceptions of the level of the state subsidies and taxation are presented in Figures 10 and 11 . Over $70 \%$ of the respondents who answered the question "How do you appreciate state's financial support?" (128 out of 140) considered that the support provided by the state is insignificant and insufficient. Over $60 \%$ of farmers considered that the taxes and fees they owe the state are high and $32 \%$ consider them moderate.

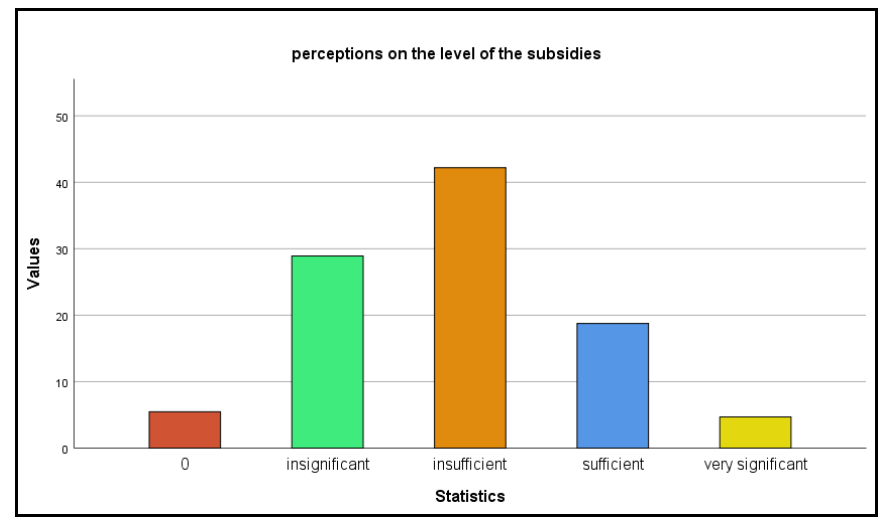

Figure 10. Farmers' perceptions on state subsidies. (Source: authors' own computations) 


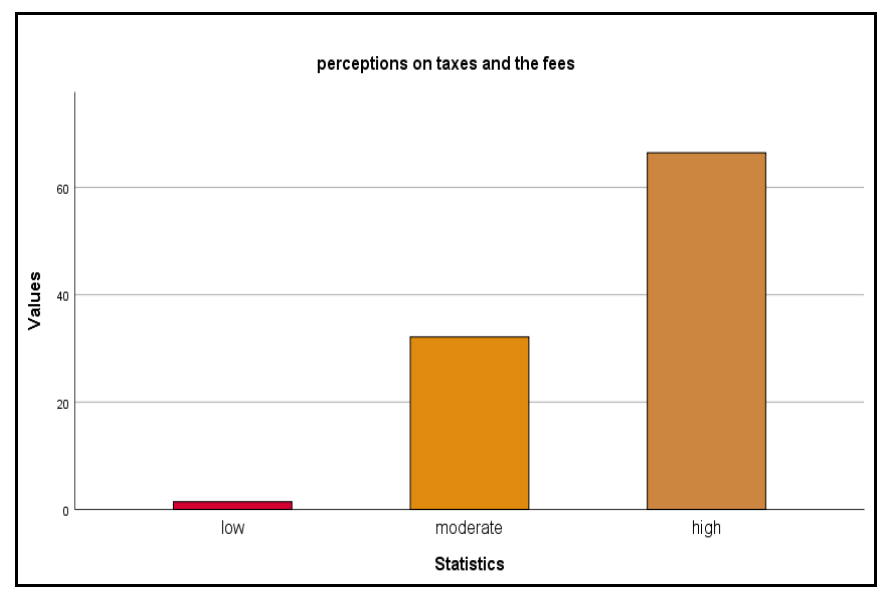

Figure 11. Farmers' perceptions on taxation. (Source: authors' own computations)

\section{Conclusions}

Farmers' willingness to associate and join in environmental responsible short supply chain in Romania is a complex and challenging research topic in Romanian agricultural economics, taking into consideration the impact of association on shaping agricultural production in modern agriculture. During the research it has been found that cooperation plays a significant role in shortened food chains and that association goes beyond simple farmers' cooperation to multi-stakeholder cooperatives. They become leading and powerful actors in food chains, since they generate a diverse range of benefits, besides economic ones: sectorial, legal, cultural, policy, academic.

The hi2 test and the contingent coefficients are used to analyze the correlations between variables. Findings indicate that the probability of farmers' membership in an associative form or in a short supply chain environmental responsible is determined by age, education level, cultivated area, activity type, year of establishment, opportunities to access financial support.

A final answer to the research question is that farmers want to involve their businesses into collective actions, since $67.1 \%$ of the farmers answered that they want to join a short supply chain, and $82.1 \%$ of them answered that they want to join an associative form of organization, in the near future. This result is opposite to those found in other research showing that $62 \%$ of subjects do not intent to associate in the future (Marin et al., 2016: p. 19).

But the association is poorly developed in Romania's agriculture, namely in the sector of vegetables and fruits, as long as only $18.6 \%$ of farmers declared that are part of an associative form of organization. Moreover, statistics show that only $1 \%$ of the Romanian agricultural producers are part of an associative form of organization.

The determinants of the farmers' affiliation to an associative form are: the type of activity, the size of the holding, the estimated revenues, access to state subsidies and farmers' occupation and education. The affiliation of farmers to a short supply chain is determined by the type of activity, the size of the holding and the level of education. As such, the hypothesis H1 is confirmed in the sense that socio-economic factors influence the farmers' willingness to join an associative form or a short supply chain with a weak to medium intensity. These results are similar to those found in the literature by Adrian et al. (2005), Marin et al. (2016), Marin et al. (2017) and Mojo et al. (2017). 
The hypothesis "Membership in a collective form of organization and a short supply chain has a positive impact on farm income and assets" (H2) is partly confirmed. The fact that farmers are part of an associative form influences their income, but not that they are part of a short supply chain.

The assumption that farmers are resistant to join a short supply chain or an associative form $(\mathrm{H} 3)$ is not confirmed, since $82.1 \%$ of respondents want to join an associative and $67.1 \%$ of respondents want to integrate their business into a short supply chain.

The assumption that farmers' reasons for not joining short supply chains and associative forms of organizations are linked to the lack of trust in other members, the lack of legislation and to bureaucracy is confirmed (H4), and consistent to other findings (Marin, 2017).

Regarding the reasons for joining the short supply chains environmental responsible and associative forms of organizations, the determinants of the farmers' willingness to associate are: the year of starting the activity, the type of activity, the size of the holding, the access to subsidies and the level of education. The farmers' willingness to join a short supply chain is determined by the year of starting the activity and the opportunity to access European funds, with intensity from weak to moderate.

Most of the farmers considered the short supply chain functional and the association as positive in shortening the chain. Over $70 \%$ of the farmers who answered the question related to the perceptions on the level of the state subsidies considered that the support provided by the state is insignificant and insufficient.

To conclude, the profile of farmers who want to associate and/or to integrate the activity into a short supply chain can be drawn. The farmers willing to associate are young, under 40 years old, with higher education, legally organized as physical persons, exploiting smaller agricultural areas. They recently started their activity and they never accessed subsidies before. The farmers willing to join a short supply chain are organized as physical persons. They have higher education and exploit smaller agricultural areas. They recently started their activity and intend to access European funds for developing their businesses. The results may be used to develop policy initiatives to finance collective actions in food supply chains environmental responsible, because they provide insights into the socio-economic factors that influence the farmers' membership in short supply chains and associative forms of organization. The current study contributes to the literature by analyzing the determinants of association and short supply chain membership using the survey data of farms gathered from vegetables and fruits producers in Romania.

\section{REFERENCES}

[1] Abate, G. T., Francesconi, G. N., Getnet, K. (2014): Impacts of agricultural cooperatives on smallholders' technical efficiency: empirical evidence from Ethiopia. - Ann. Public. Coop. Econ. 85. 257-286.

[2] Adrian, A. M., Norwood, S. H., Mask, P. L. (2005): Producers' perceptions and attitudes toward precision agriculture technologies. - Computers and Electronics in Agriculture 48(3): 256-271. http://dx.doi.org/10.1016/j.compag.2005.04.004.

[3] Aligica, P. D., Dabu, A. (2003): Land reform and agricultural reform policies in Romania's transition to the market economy. - Eastern European Economics 41(5): 4969. 
[4] Aničić, D., Obradović, M., \& Vukotić, S. (2018): Impact of economic policy on the management of competitiveness of the agriculture sector in Serbia. - Economics of Agriculture 65(1): 187-200.

[5] Baggini, J. (2014): The Virtues of the Table: How to Eat and Think. - Granta Books, London.

[6] Bauwens, M., Kostakis, V. (2014): From the communism of capital to capital for the commons: towards an open co-operativism. - Journal from a Global Sustainable Information Society 12(1): 356-361. https://doi.org/10.31269/triplec.v12i1.561.

[7] Bernard, T., Spielman, D. J., Seyoum Taffesse, A., Gabre-Madhin, E. Z. (2010): Cooperatives for Stable Crop Marketing: Evidence from Ethiopia. - Int. Food Policy Res. Inst., Washington, DC.

[8] Bernard, T., Abate, G., Lemma, S. (2013): Agricultural cooperatives in Ethiopia: Results of the 2012 ATA Baseline Survey. - International Food Policy Research Institute, Washington, DC.

[9] Bonin, J. P., Jones, D. C., Putterman, L. (1993): Theoretical and empirical studies of producer cooperatives: will ever the twain meet? - Journal of Economic Literature 31(3): 1290-1320.

[10] Bontems, P., Fulton, M. (2009): Organizational structure, redistribution and the endogeneity of cost: cooperatives, investor-owned firms and the cost of procurement. Journal of Economic Behavior and Organization 72(1): 322-343.

[11] Burton, R. (2004): Reconceptualising the 'behavioural approach' in agricultural studies: a socio-psychological perspective. - Journal of Rural Studies 20(3): 359-371.

[12] Camanzi, L., Malorgio, G., Garcia Azcarate, T. (2011): The role of producer organizations in supply concentration and marketing: a comparison between European countries in the fruit and vegetable sector. - Journal of Food Products Marketing 17(2-3): 327-354.

[13] Cartwright, A. L. (2017): The Return of the Peasant: Land Reform in Post-Communist Romania. - Routledge, London.

[14] Centrul Român de Politici Europene (CRPE) (2016): Asocierea - element cheie pentru dezvoltarea agriculturii în România. - https://www.crpe.ro/analiza-cantitativa-sectoruluiasociativ-agricol-romanesc/.

[15] Chirwa, E., Dorward, A., Kachule, R., Kumwenda, I., Kydd, J., Poole, N. D., Poulton, C., Stockbridge, M. (2005): Walking Tightropes: Supporting Farmer Organisations for Market Access. ODI Natural Resource Perspectives. - Overseas Development Institute, London.

[16] Constantin, C., Luminița, C., Vasile, A. J. (2017): Land grabbing: A review of extent and possible consequences in Romania. - Land Use Policy 62: 143-150.

[17] Cook, M. L., Chaddad, F. R. (2004): Redesigning cooperative boundaries: the emergence of new models. - American Journal of Agricultural Economics 86(5): 1249-1253.

[18] Dale, P., Baldwin, R. (2000): Emerging land markets in Central and Eastern Europe. World Bank Technical Paper 465: 81-109.

[19] Dani, S., Deep, A. (2010): Fragile food supply chains: reacting to risks. - International Journal of Logistics Research and Applications 13(5): 395-410.

[20] Davidova, S., Buchenrieder, G., Cristou, A., Coulomb, C. (2003): Romanian Agriculture and Transition toward the EU. - Lexington Books, Lanham, MD.

[21] Donovan, J., Stoian, D. and Poole, N. D. (2008): Global Review of Rural Enterprises: The Long and Winding Road to Creating Viable Businesses and Potential Shortcuts. Tropical Agricultural Research and Higher Education Center, Turrialba.

[22] Fischer, E, Qaim, M. (2012): Linking smallholders to markets: determinants and impacts of farmers collective action in Kenya. - World Development 40: 1255-1268.

[23] Folorunso, O., Ogunseye, S. O. (2008): Applying an enhanced technology acceptance model to knowledge management in agricultural extension services. - Data Science Journal 7: 31-45. https://http://dx.doi.org/10.2481/dsj.7.31. 
[24] Food and Agricultural Organisation of the United Nation (FAO) (2005): Increasing the contribution of small-scale fisheries to poverty alleviation and food security. - FAO Technical Guidelines for Responsible Fisheries No. 10. Rome. www.fao.org/docrep/009/a0237e/a0237e00.htm.

[25] Food and Agricultural Organisation of the United Nation (FAO) (2012): Agricultural Cooperatives: Key to Feeding the World. World Food Day Leaflet. - FAO, Rome.

[26] Gonzales, R. A. (2017): Going back to go forwards? From multi-stakeholder cooperatives to Open Cooperatives in food and farming. - Journal of Rural Studies 53: 278-290.

[27] Gray, T. W., Stevenson, G. W. (2008): Cooperative Structure for the Middle: Mobilizing for Power and Identity. - In: Lyson, T. A., Stevenson, G. W., Welsh, R. (eds.) Food and the Mid-Level Farm. MIT Press, Cambridge, pp. 37-53.

[28] Hansson, H., Ferguson, R., Olofsson, C. (2012): Psychological constructs underlying farmers' decisions to diversify or specialise their businesses - an application of theory of planned behaviour. - Journal of Agricultural Economics 63: 465-482. http://dx.doi.org/10.1111/j. 1477-9552.2012.00344.x.

[29] Hartvigsen, M. (2014): Land reform and land fragmentation in Central and Eastern Europe. - Land Use Policy 36: 330-341.

[30] Heyder, M., Hespos, T. H., Theuvsen, L. (2010): Agribusiness firm reactions to regulations: the case of investments in traceability systems. - International Journal on Food System Dynamics 2: 133-142. http://dx.doi.org/10.18461/ijfsd.v1i2.125.

[31] Hu, R., Lin, M., Shieh, C. J. (2018): Performance evaluation of basic-level farmers' associations introducing customer relationship management. - Custos E Agronegocio On Line 14(2): 411-421.

[32] International Co-operative Aliance (ICA) (2018): Co-operative identity, values \& principles. - https://ica.coop/en/whats-co-op/co-operative-identity-values-principles.

[33] Ion, R. A. (2005): The Performance of the Agro-food System in Romania. [Performanţa sistemului agroalimentar din România]. - CERES, Bucharest.

[34] Ion, R. A. (2015): Fruits and vegetables market in Romania: better understand consumer preferences. - Proceedings of the Symposium Agricultural Economics and Rural Development - Realities and perspectives for Romania, 20-21 November, 2015, Bucharest, Romania, pp.426-433.

[35] Knowler, D., Bradshaw, B. (2007): Farmers' adoption of conservation agriculture: A review and synthesis of recent research. - Food Policy 32: 25-48.

[36] Kuemmerle, T., Müller, D., Griffiths, P., Rusu, M. (2009): Land use change in Southern Romania after the collapse of socialism. - Regional Environmental Change 9(1): 1.

[37] Lang, T., Barling, D., Caraher, M. (2009): Food Policy. Integrating Health, Environment and Society. - Oxford University Press, Oxford.

[38] Lerman, Z., Csaki, C., Feder, G. (2004): Agriculture in Transition: Land Policies and Evolving Farm Structures in Post-Soviet Countries. - Lexington Books, Lanham, MD.

[39] Lund, M. (2012): Multi-stakeholder co-operatives: engines of innovation for building a healthier local food system and a healthier economy. - Journal of Co-Operative Studies 45(1): 32-45.

[40] Malassis, L., Ghersi, G., collectif, (1992): Initiation in Agro-food Economy. [Initiation a l'economie agro-alimentaire]. - Haitier, Paris.

[41] Mănescu, C., Cristina, A. F., Sicoe-Murg, O., Găvruţa, A., Mateoc, T., Toth, A., MateocSirb, N. (2016): Analysis of the importance of agriculture sector in Romanian economy. Scientific Papers: Management, Economic Engineering in Agriculture \& Rural Development 16(1): 271-277.

[42] Manole, V., Istudor, N., Boboc, D., and Ion, R., A. (2005): Agro-Food Value Chains. [Filiere agroalimentare]. - Editura ASE, Bucharest.

[43] Marin, A., Ion, R. A., Dobre, I., Chetroiu, R., Iurchievici, L., Pop, R. E., Tudor, V., Micu, M. M., Costache, M. (2016): Designing and Experimenting Models for the Development of Short Chains for Vegetable Production. [Proiectarea şi experimentarea de modele de 
dezvoltare a lanţurilor scurte de valorificare a producţiei de legume]. - Editura ASE, Bucharest.

[44] Marin, A., Ion, R. A., Chetroiu, R., Iurchevici, L. (2017): Designing and Experimenting Models for the Development of Short Chains for Fruit Production. [Proiectarea şi experimentarea de modele de dezvoltare a lanţurilor scurte de valorificare a producţiei de fructe]. - Editura ASE, Bucharest.

[45] Markelova, H., Meinzen-Dick, R., Hellin, J., Dohrn, S. (2009): Collective action for smallholder market access. - Food Policy 34(1): 1-7.

[46] Marsden, T., Banks, J., Bristow, G. (2002): The Social Management of Rural Nature: Understanding Agrarian-based Rural Development. - Environment and Planning A 34: 809-825.

[47] Ministry of Agriculture and Rural Development of Romania (MARD) (2016): Applicant's Guide to Sub-Measure 16.4 and Sub-Measure 16.4a. file:///D:/Documente/Doc_2018/cercetare/PNDR/Ghidul_Solicitantului_sM16.4-16.4a__decembrie_2016.pdf.

[48] Ministry of Agriculture and Rural Development of Romania (MARD) (2017): The National Program for Rural Development 2014-2020. http://www.madr.ro/docs/dezvoltare-rurala/PNDR-2014-2020-versiunea-aprobata-30iunie-2017.pdf.

[49] Mojo, D., Fischer, C., Degefa, T. (2017): The determinants and economic impacts of membership in coffee farm cooperatives: recent evidence from rural Ethiopia. - Journal of Rural Studies (50) 84-94.

[50] Montefrio, M. J. (2016): Cooperation and resistance: Negotiating rubber in upland Philippines. - Journal of Rural Studies 46: 111-120.

[51] Mooney, P. H. (2004): Democratizing rural economy: institutional friction, sustainable struggle and the cooperative movement. - Journal of Rural Sociology 69(1): 76-98.

[52] Narrod, C., Roy, D., Okello, J., Avendano, B., Rich, K., Thorat, A. (2009): Public-private partnership and collective action in high value fruit and vegetable supply chains. - Food Pol. 34: 8-15.

[53] National Institute of Statistic of Romania (NIS) (2018): Farm Structure Survey 2016. NIS, Bucharest.

[54] Neven, D., Reardon, T. (2004): The rise of Kenyan supermarkets and the evolution of their horticulture product procurement systems. - Development Policy Review 22(6): 669-699.

[55] New, S. J. (1997): The scope of supply chain management research. - Supply Chain Management 2(1): 15-22.

[56] Nosenzo, D., Tufano, F. (2017): The effect of voluntary participation on cooperation. Journal of Economic Behavior \& Organization 142: 307-319.

[57] Pappa, I. C., Iliopoulos, C., Massouras, T. (2018): What determines the acceptance and use of electronic traceability systems in agri-food supply chains? - Journal of Rural Studies. 58: 123-135. https://doi.org/10.1016/j.jrurstud.2018.01.001.

[58] Poole, N., Frece, A. (2010): A Review of Existing Organisational Forms of Smallholder Farmers' Associations and their Contractual Relationships with other Market Participants in the East and Southern African ACP Region. - AAACP Paper Series - No. 11. Food and Agricultural Organization, Rome.

[59] Porojan, D. (1993): Statistica si teoria sondajului [Statistics and Theory of Sampling]. Sansa, Bucharest.

[60] Prager, K. (2015): Agri-environmental collaboratives for landscape management in Europe. - Current Opinion in Environmental Sustainability 12: 59-66. https://doi.org/10.1016/j.cosust.2014.10.009.

[61] Prokopy, L., Floress, K., Klotthor-Weinkauf, D., Baumgart-Getz, A. (2008): Determinants of agricultural best management practice adoption: evidence from the literature. - Journal of Soil and Water Conservation 63(5): 300-311. 
[62] Romanian Government Decision no.740/2017 regarding the granting financial aid to producer organizations and other associative forms for marketing in the fruit and vegetables sector. $\quad-\quad$ http://www.apia.org.ro/files/pages_files/HG_7402017_Document.pdf. Official Monitor of Romania, no.810/2017.

[63] Sabates-Wheeler, R. (2001): Land reform and farm choice in Romania. - Problems of Post-Communism 48(4): 27-37.

[64] Sikor, T., Müller, D., Stahl, J. (2009): Land fragmentation and cropland abandonment in Albania: Implications for the roles of state and community in post-socialist land consolidation. - World Development 37(8): 1411-1423.

[65] Stone, J., Rahimifard, S. (2018): Resilience in agri-food supply chains: a critical analysis of the literature and synthesis of a novel framework. - Supply Chain Management: An International Journal 23(3). https://doi.org/10.1108/SCM-06-2017-0201.

[66] Thomas, J. (2006): Property rights, land fragmentation and the emerging structure of agriculture in Central and Eastern European countries. - Journal of Agricultural and Development Economics 3(2): 225-275.

[67] Turek Rahoveanu, A., Zahiu, L., Turek Rahoveanu, M., Alexandri, C., Popescu, A., Dachin, A., Ion, R. A. (2007): Competitiveness on Cereals' Supply Chain. [Competitivitatea pe filiera cerealelor panificabile]. - Cartea Universitara, Bucharest.

[68] Van der Ploeg, J. D., Franco, J. C., Borras Jr, S. M. (2015): Land concentration and land grabbing in Europe: a preliminary analysis. - Canadian Journal of Development Studies/Revue canadienne d'études du développement 36(2): 147-162.

[69] Vidican, G. (2009): Assessing land reallocation decisions during transition in Romania. Land Use Policy 26(4): 1080-1089.

[70] Williamson, O. E. (1985): The Economic Institutions of Capitalism. - Macmillan, New York.

[71] Wynne-Jones, S. (2017): Understanding farmer co-operation: Exploring practices of social relatedness and emergent affects. - Journal of Rural Studies 53: 259-268.

[72] Zhong, H. (2016): Essays on Farmer Willingness to Participate in Best Management Practices in the Kentucky River Watershed. - Thesis and Dissertations, Agricultural Economics, University of Kentucky. http://dx.doi.org/10.13023/ETD.2016.234. 